\title{
Diagnose the Earth
}

\section{Li Zhou}

School of Chemical Engineering and Technology, Tianjin University, Tianjin, China

Email: zhouli@tju.edu.cn

How to cite this paper: Zhou, L. (2018) Diagnose the Earth. Low Carbon Economy, 9, 75-79.

https://doi.org/10.4236/lce.2018.93006

Received: July 30, 2018

Accepted: September 4, 2018

Published: September 7, 2018

Copyright (C) 2018 by author and Scientific Research Publishing Inc. This work is licensed under the Creative Commons Attribution International License (CC BY 4.0).

http://creativecommons.org/licenses/by/4.0/

\begin{abstract}
The earth is sick and the present work explains how it gets ill and how serious the decease is. It is shown that the illness originates in over dense population since present population is 7.6 billion while 1.3 billion is the breakeven point of the earth for $\mathrm{CO}_{2}$ metabolism and 6.7 billion is the upper limit to maintain a quasi-equilibrium state for the metabolism. More and more greenhouse gases emit into atmosphere from underground and undersea, and warming up process is accelerated. Utilization of clean energy cannot save the earth, but to pray a little ice age coming soon. What humanity can and should do is to use zero-emitted coal power and change the fertility rate to negative.
\end{abstract}

\section{Keywords}

Diagnose, Earth, $\mathrm{CO}_{2}$-Emission, Population, Recipe

\section{The Earth Is Sick}

The earth gets ill and warms up continuously for recent years as shown in Figure 1 [1]. This observation was thought of natural periodic change by few scholars; however, it is commonly attributed to the higher than normal concentration of $\mathrm{CO}_{2}$ in atmosphere, which causes greenhouse effect. Therefore, agreements on reducing emission of $\mathrm{CO}_{2}$ have been reached, and multi clean energies have been encouraged to develop. The earth is obviously disturbed by human activities too much when the population becomes too dense. There are two points that must be made clear. First, food and fuel are inevitable for human activities, and both of them yield greenhouse gases; therefore, clean energy alone cannot save the earth from illness; second, how much population is too dense to be intolerable by the earth?

To make the second point clear, a figure of global $\mathrm{CO}_{2}$ emission versus world population was drawn for the period 1850-2008 as shown in Figure 2(a) [2]. It indicates that population of 1.3 billion is the breakeven point of earth for 


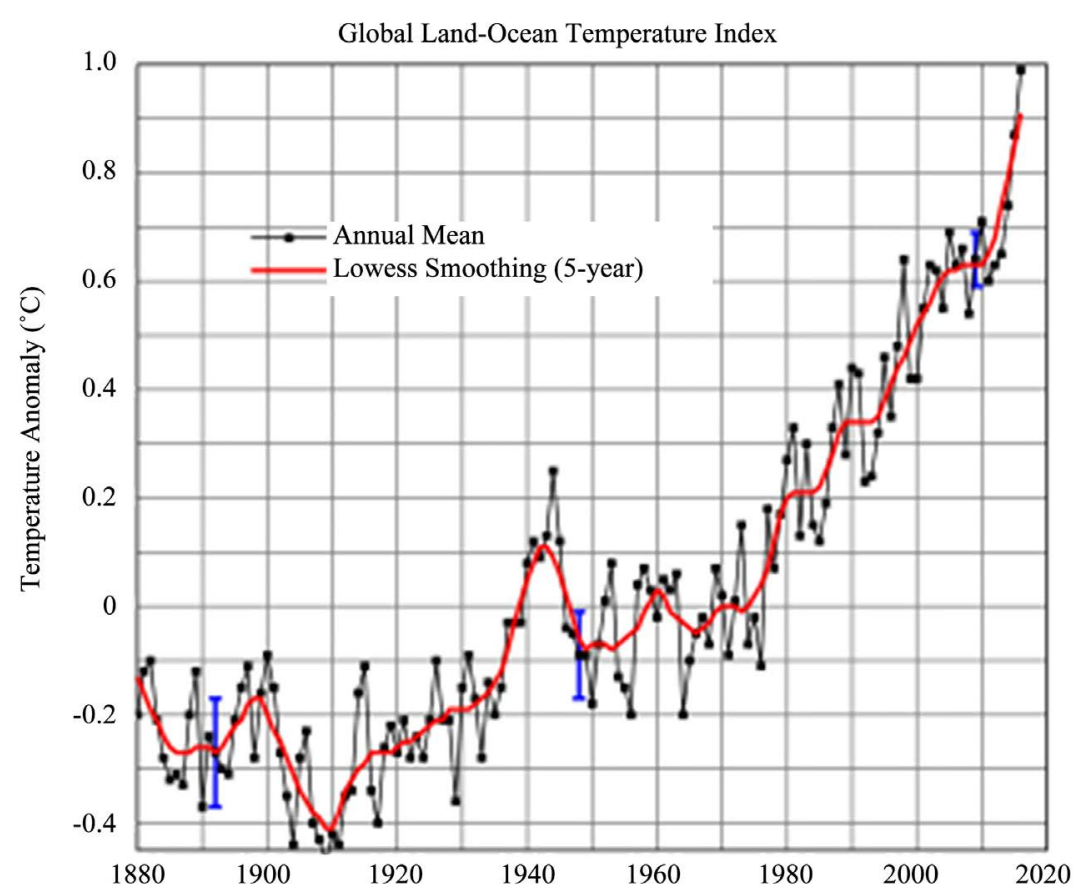

Figure 1. Global mean surface-temperature change from 1880 to 2016 relative to the 1951-1980 mean [1].

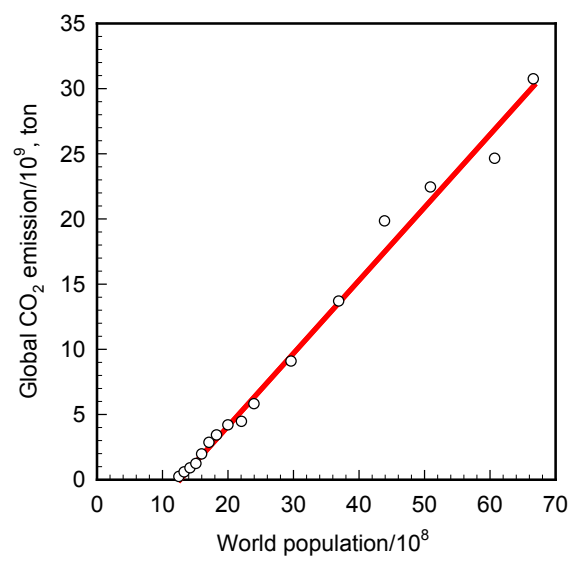

(a)

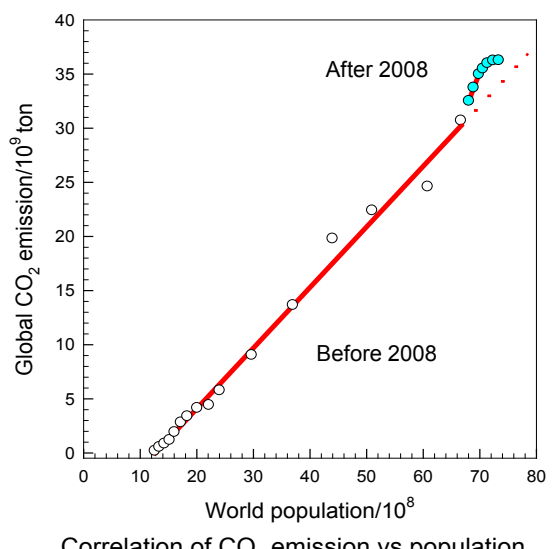

Correlation of $\mathrm{CO}_{2}$ emission vs population

(b)

Figure 2. (a) Relationship between global emission of $\mathrm{CO}_{2}$ and world population for 1850-2008 [2]; (b) [3].

$\mathrm{CO}_{2}$-metabolism, less than which no $\mathrm{CO}_{2}$ emission at all, and more than which $\mathrm{CO}_{2}$ emitted and linearly increased with population. In conclusion, the fever of the earth originates in over-population because warming up is caused by the greenhouse effect.

\section{The State of Illness Is Serious}

The corresponding data of global $\mathrm{CO}_{2}$ emission and world population for recent years were added to Figure 2(a) and shown in Figure 2(b) with blue dots [3]. The per capita emission of $\mathrm{CO}_{2}$ is constant as is indicated in Figure 2(a). How- 
ever, this quantity becomes remarkably higher than the previous constant after 2008. How come? In fact, the global $\mathrm{CO}_{2}$ emission increases quite slowly since 2008 as shown in Figure 3 [4], and the world population does not stop to increase; therefore, the per capita $\mathrm{CO}_{2}$ emission is expected to be lower than previous. The abnormal behavior is explained when we look at the news of Siberian's "Gates of Hell" (Figure 4) [5] and similar reports on the melting of permafrost land and Antarctic ices about the same time. A huge quantity of carbon dioxide and methane is emitted into atmosphere from underground or undersea accompanying the melting/warming process. In addition to greenhouse gases, ancient virus and bacteria get also exposure to the atmosphere. The melting of permafrost land is a milestone for the process of global warming since more and more greenhouse gases will enter atmosphere limitlessly and irreversibly. This happens when the world population reaches 6.7 billion at 2008. Therefore, population of 6.7 billion is the upper limit for a safe earth, beyond which the earth would become unlivable. The present population is 7.6 billion. It means the earth is seriously sick.

\section{The Recipe}

There is no way to cure the earth at present unless a little ice age soon comes. The permafrost land will freeze again and the world population will reduce considerably for a period of little ice age. We cannot just to wait passively, we must do something proactive. First of all, the world population must be purposely and drastically reduced. Most developing countries think ample labor source is active for their economy and encourage fertility. However, humanity steps to a crux at present: to develop economy or to survive. The world population must anyway be drawn back to less than 6.7 billion. The time left is not much since population increases exponentially. For example, the population will double (15.2 billion) in 72 years if the present average growing rate is of about $1 \%$. Everybody of the world must be conscious of the serious situation that humanity faces and do what he/she should do.

Although clean energy cannot save the earth from illness, $\mathrm{CO}_{2}$-emission must be stopped, sooner the better. To my opinion, coal power is the unique option of energy source because it can be made zero-emission with low cost. In addition, coal is of widespread distribution and abundant storage. To realize zero emission, coal-fired power plants must quit any so-called clean coal technology known to today since none of them capture $\mathrm{CO}_{2}$, nor thoroughly capture acid gases and ultrafine dust, rather high cost is paid though. The method is quite simple and technically matured as shown in Figure 5. The post combustion flue gas of temperature higher than $500^{\circ} \mathrm{C}$ is heated to $700^{\circ} \mathrm{C}-750^{\circ} \mathrm{C}$ and then flows into a gas/solid reactor and reacts with carbon. The $\mathrm{SO}_{x}$ is reduced to pure sulfur and $\mathrm{NO}_{x}$ reduced to nitrogen. The gas mixture experienced twice cooling yielding sulfur and water consecutively. Because fine dusts are the nuclei of vapor condensation, they are removed with water the same time. The remaining gases 


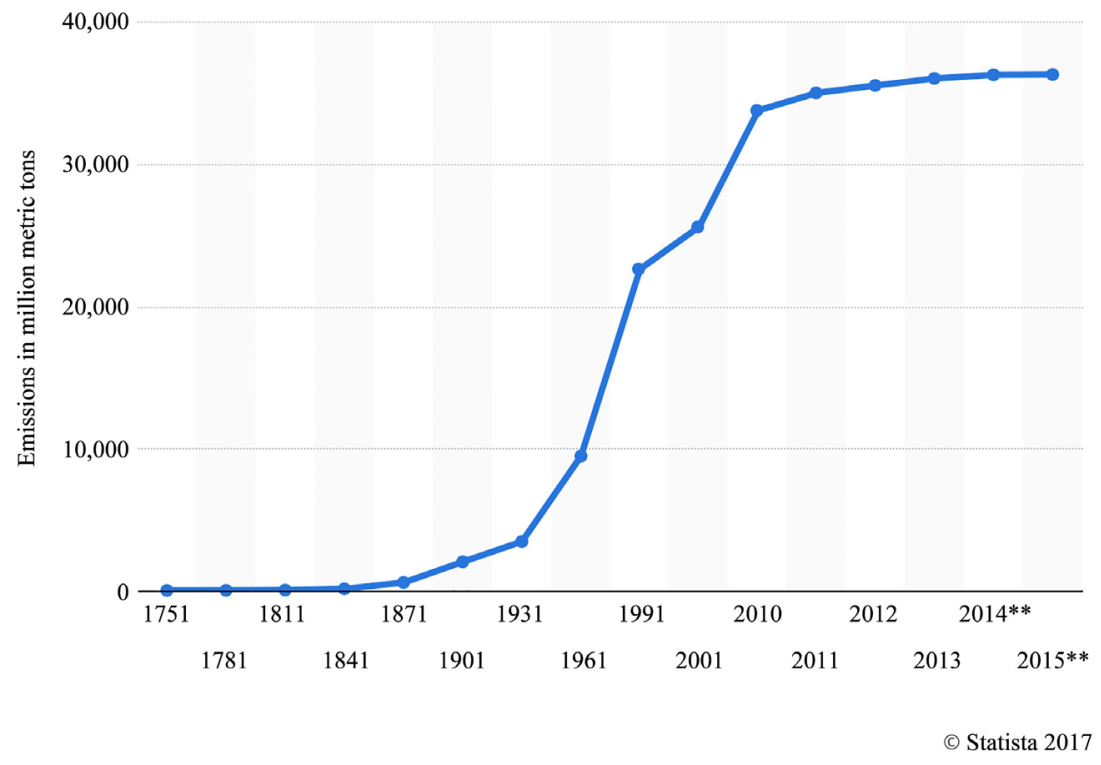

Figure 3. Global $\mathrm{CO}_{2}$ emission for 1751-2015 [4].

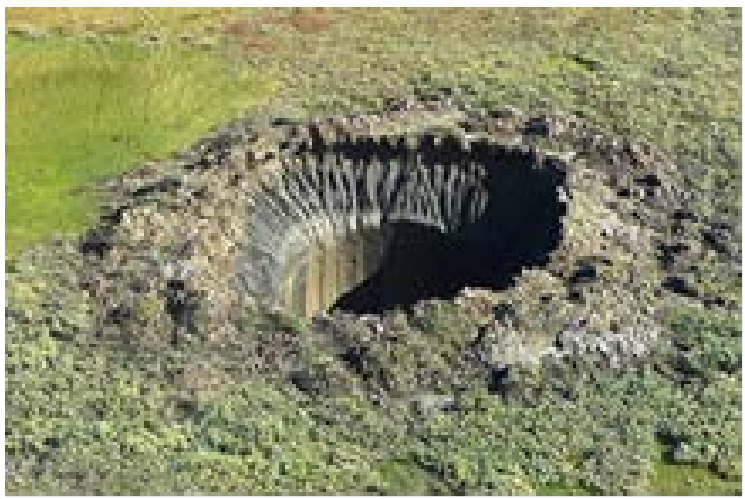

Figure 4. Siberian's gate of the hell [5].

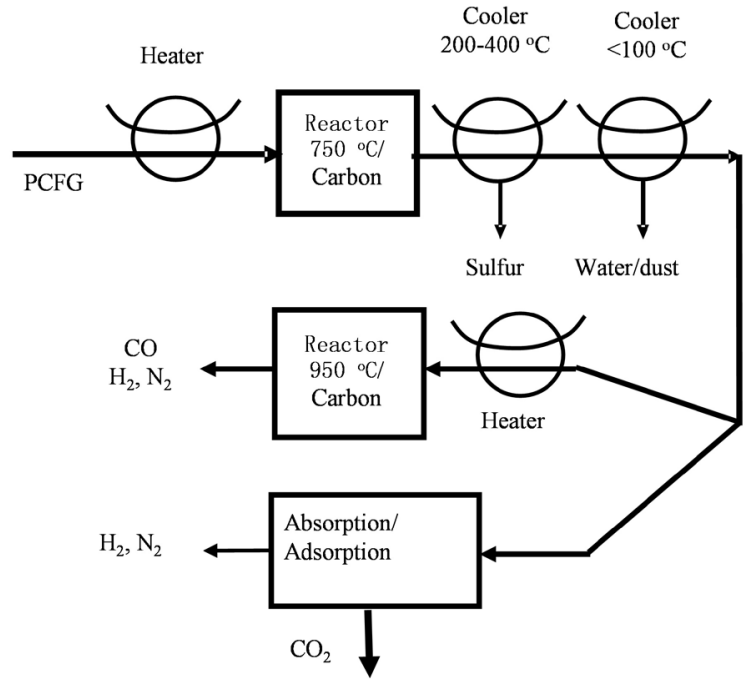

Figure 5. Flow sheet of processing the flue gas of coal-fired power plants (PCFG: post-combustion flue gas) [9]. 
may have two treatments depending on the succeeding routine of chemical synthesis. It is heated to $950^{\circ} \mathrm{C}$ and reacts with carbon again if the synthesis starts with carbon monoxide; it directly flows into an absorption/adsorption column to separate $\mathrm{CO}_{2}$ from others if the synthesis starts with $\mathrm{CO}_{2}$. Carbon dioxide is fixed in chemicals anyway, and the forced carbon circulation (FCC) strategy [6] is thus carried out. The chemical principle and laboratory experiments to support the feasibility of the processing are previously presented [7] [8].

When coal-fired power plants are retrofitted to zero-emission, electric vehicles are genuine clean. Oil and gas are better avoided because of higher cost and higher strategic risks. All available clean energies remaining in market may fail to compete with coal power due to higher cost. As to the concern of sustainability, it might be meaningless since the coal resources can satisfy the world need for several hundred years, and this generation of civilization may not survive for that long if the fertility problem cannot be soon solved.

\section{Conflicts of Interest}

The author declares no conflicts of interest regarding the publication of this paper.

\section{References}

[1] Global Warming. Wikipedia. https://en.wikipedia.org/wiki/Global_warming

[2] Zhou, L. (2012) Carbon Emission: Invalid Strategy and Ecological Rule. Low Carbon Economy, 3, 80-82. https://doi.org/10.4236/lce.2012.323011

[3] Zhou, L. (2018) Population Controls Environment. Journal of Social Sciences Research, 4, 55-57. http://arpgweb.com/?ic=journal\&journal=7\&info=aims

[4] Energy \& Environmental Services, Emissions, Global $\mathrm{CO}_{2}$ Emissions 1751-2015. https://www.statista.com/statistics/264699/worldwide-co2-emissions/

[5] http://www.imwb.gov.cn/xwzx/qhbh/xwbb/644792.shtml

[6] Zhou, L. (2014) Environmental Pollution: The Essence and Solution. Low Carbon Economy, 5, 51-56. https://doi.org/10.4236/lce.2014.52006

[7] Zhou, L. (2014) The Chemical Proof for Zero-Emission of Coal Combustion. 39th International Technical Conference on Clean Coal \& Fuel Systems, Clearwater, FL, 2-6 June 2013.

[8] Zhou, L. (2014) The Chemical Principle of Green Coal Power. Journal of Energy and Power Engineering, 8, 1918-1925.

[9] Zhou, L. (2016) Comments on Energy and Environment Problem. Sustainable Energy, 6, 79-90. http://creativecommons.org/licenses/by/4.0/ 